\title{
Concentration of HLLW from Future SNF Recycling for Efficient Immobilization in a CCIM FCRD-SWF-2014-000256
}

Vince Maio and Veronica Rutledge

April 2014

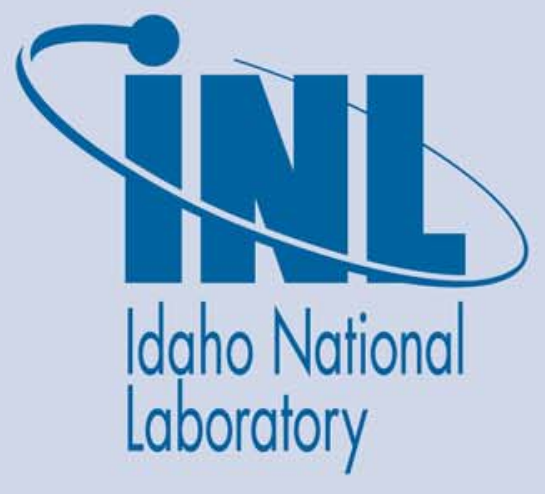

The INL is a U.S. Department of Energy National Laboratory operated by Battelle Energy Alliance 


\section{DISCLAIMER}

This information was prepared as an account of work sponsored by an agency of the U.S. Government. Neither the U.S. Government nor any agency thereof, nor any of their employees, makes any warranty, expressed or implied, or assumes any legal liability or responsibility for the accuracy, completeness, or usefulness, of any information, apparatus, product, or process disclosed, or represents that its use would not infringe privately owned rights. References herein to any specific commercial product, process, or service by trade name, trade mark, manufacturer, or otherwise, does not necessarily constitute or imply its endorsement, recommendation, or favoring by the U.S. Government or any agency thereof. The views and opinions of authors expressed herein do not necessarily state or reflect those of the U.S. Government or any agency thereof. 
INL/EXT-13-28484

Revision 0

\title{
Concentration of HLLW from Future SNF Recycling for Efficient Immobilization in a CCIM FCRD-SWF-2014-000256
}

\author{
Vince Maio and Veronica Rutledge
}

April 2014

\begin{abstract}
Idaho National Laboratory
DOE-NE/Fuel Cycle Research and Development

Separations and Waste Forms

Project 1.02.03.08 FT-13/14IN030801/7-Cold Crucible Induction Melter Test with GlassCeramic Waste Forms-INL

Milestone Level 4M4FT-13IN0308012 "Issue Waste Concentration Basis Report" \& part of Milestone Level 4M4FT-140308074 "Publish 3 Pending FY-12/13 CCIM Reports"

Idaho Falls, Idaho 83415

http://www.inl.gov
\end{abstract}

Prepared for the

U.S. Department of Energy

Office of Nuclear Energy (NE)

Under DOE Idaho Operations Office

Contract DE-AC07-05ID14517 


\begin{abstract}
Sponsored by the Department of Energy Nuclear Energy's Fuel Cycle Research and Development Program, the Cold Crucible Induction Melter is being developed as the next generation of melter technology for High Level Liquid Waste's efficient immobilization in highly durable glass ceramic and ceramic forms. Concentration of the radioactive High Level Liquid Waste generated from the proposed future recycling of spent nuclear fuel, after the fuel's dissolution in nitric acid, is necessary to take advantage of the inherent attributes of Cold Crucible Induction Melting technology. Based on a range of commercial spent nuclear fuel fission product composition data and its expected High Level Liquid Waste composition data as provided in oxide form, an analysis was completed to estimate a reliable concentration level for the waste. The analysis involved using nitric acid vapor liquid equilibrium data over a range of boiling temperatures and performing spreadsheet calculations to concentrate the High Level Liquid Waste through evaporation. The results will provide a concentrated nonradioactive surrogate High Level Liquid Waste feed recipe for testing in Idaho National Laboratory's Cold Crucible Induction Melter Pilot Plant. This testing will generate data to begin verification of the relatively high feed rates of Cold Crucible Induction Melters compared to those of ceramic lined Joule Heated Melters.
\end{abstract}




\section{CONTENTS}

Abstract. vi

Acronyms, Units and Symbols . viii

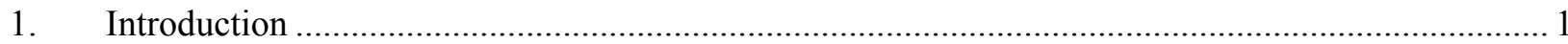

2. HLLW Concentration Approach and Calculations.................................................................... 2

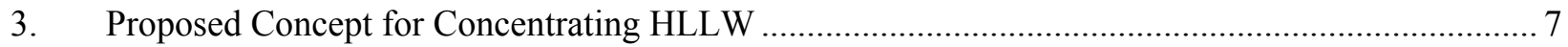

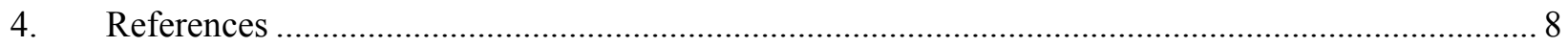

\section{FIGURES}

Figure 1 Left picture- Compared to a JHM, the lack of in-melt electrodes and refractory in a CCIM allow for greater mixing, longer life, greater throughput, less footprint and temperatures exceeding $1700^{\circ} \mathrm{C}$, Right picture- The $26.1 \mathrm{~cm}$ diameter, 6 turn (induction coil) crucible of the INL's CCIM Pilot Plant inside its Faraday cage........................ 1

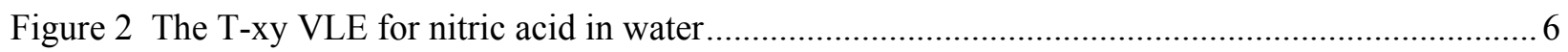

\section{TABLES}

Table 2 HLLW species concentrations before and after concentrating the waste via evaporation. All compositions are on a basis of 100 grams of solid oxide. .5

Table 3 Volume and solids content before and after concentrating the HLLW 7 


\section{Acronyms, Units and Symbols}

CCIM Cold Crucible Induction Melter

DOE-NE Department of Energy Nuclear Energy Program

FCRD Fuel Cycle Research and Development (Program)

g/1 grams per liter (component concentration in HLLW)

$\mathrm{g} / \mathrm{ml} \quad$ grams per milliliter

GWD/MT Units of reactor fuel burn up expressed as gigawatt-days (thermal) per metric tons of original heavy metal in the (spent) nuclear fuel

HLLW High Level Liquid Waste

INL Idaho National Laboratory

JHM Joule Heated Melter

$\mathrm{kg} / \mathrm{l} \quad$ kilograms per liter

M Molarity (concentration of HLLW component in moles per liter of solution)

$\mathrm{NO}_{\mathrm{X}} \quad$ Nitrous oxide gas $\left(\mathrm{NO}_{2}\right.$ and $\left.\mathrm{NO}\right)$

PNNL Pacific Northwest National Laboratory

SWF Separations and Waste Forms

T-xy Boiling (Bubble) temperature equilibrium curve for a two phase system of components $\mathrm{x}$ and y (nitric acid and water)

SCR Selective Catalytic Induction ( $\mathrm{NO}_{\mathrm{X}}$ removal system)

SNF Spent Nuclear Fuel

VLE Vapor Liquid Equilibrium (for Nitric Acid)

wt.\% Weight Percent 


\section{Concentration of HLLW from Future SNF Recycling for Efficient Immobilization in a CCIM}

\section{Introduction}

Radioactive High Level Liquid Waste (HLLW) generated from the potential future recycling of spent nuclear fuel (SNF) will be high in water and nitrate content if the recycling method is aqueous based. The cause of this dilute HLLW is the nitric acid solution ( $\sim 5$ to $8 \mathrm{M})$ used to dissolve the oxide fuel prior to the aqueous separation cycles. This HLLW contains few undissolved solids prior to addition of the immobilization additives needed for melting into a solid form for disposal. As a result, this HLLW has a density of only $\sim 1.1 . \mathrm{g} / \mathrm{ml}$ and is of low viscosity.

FY 2012 testing for HLLW immobilization development involving nonradioactive glass ceramic waste forms in Idaho National Laboratory's (INL's) Cold Crucible Induction Melter (CCIM) Pilot Plant indicated that surrogates of the proposed HLLW were too dilute to be efficiently fed to the melter to take advantage of CCIM technology. Dilute melter feeds expend a high percentage of the CCIM's energy for water evaporation and denitration. Instead, this energy should be directed to melting the radioactive components into durable forms. The dilute simulated HLLW limits the high waste throughput benefits offered by CCIM technology; which is potentially $40 \%$ higher compared to lower temperature Joule Heated Melters (JHMs) currently deployed. See Figure 1.

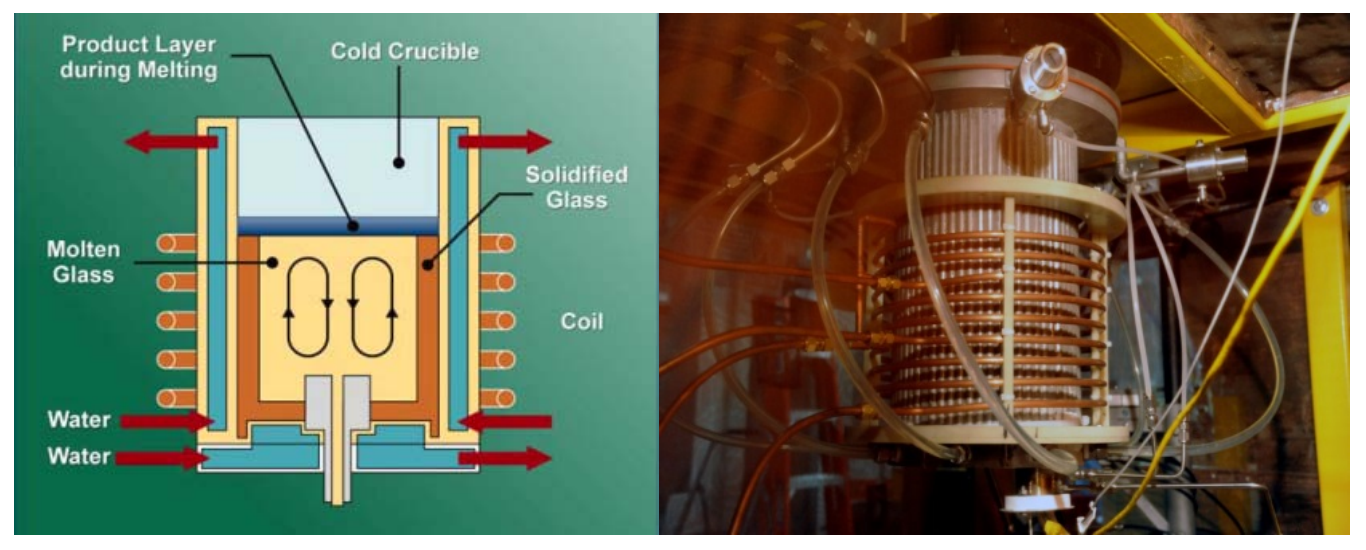

Figure 1 Left picture- Compared to a JHM, the lack of in-melt electrodes and refractory in a CCIM allow for greater mixing, longer life, greater throughput, less footprint and temperatures exceeding $1700^{\circ} \mathrm{C}$, Right picture- The $26.1 \mathrm{~cm}$ diameter, 6 turn (induction coil) crucible of the INL's CCIM Pilot Plant inside its Faraday cage.

Since there are other advantages (e.g., sufficient CCIM cold cap production, faster CCIM bed turnover) of HLLW having a greater density, higher solid levels, and a greater viscosity; methods were evaluated to concentrate the proposed dilute HLLW prior to feeding to a CCIM for immobilization. One aggressive alternative used in England, France, Japan and elsewhere involves the solidification of the HLLW into a particulate through calcination in a rotary kiln or similar drying equipment prior to melting. This alternative is not being considered for US domestic fuel cycles; since, even though calcination provides maximum volume reduction and eliminates any need for nitrous oxide $\left(\mathrm{NO}_{\mathrm{X}}\right)$ gas abatement downstream of the melter, the 
presence of radioactive particulate creates cost prohibitive contaminant issues and pre- melter equipment increases cell height and complexity. Presently, concentration of HLLW through evaporation is the preferred option and the methodology and results of calculations to estimate a concentration level is provided in the following section. This section is followed with a description of a proposed evaporation method, thermo syphon evaporation, for coupling upstream to the CCIM.

\section{HLLW Concentration Approach and Calculations}

Calculations for estimating a concentration level for dilute HLLW originated from spreadsheet calculations performed by Pacific Northwest National Laboratory (PNNL) based on comprehensive information on commercial SNF in interim storage. The information and subsequent PNNL calculations were performed under the following assumptions:

1. The composition of the fuel was taken as the average after a fuel burn up in the range of $25-$ $100 \mathrm{GWD} / \mathrm{MTIHM}$ (thermal) and a storage cooling decay time over the range of $10-50$ years.

2. $100 \%$ of the gaseous fission products were assumed removed in the de-cladding, voloxidation and dissolver steps upstream of the separation cycles.

3. $100 \%$ of the uranium and plutonium were removed by the advanced SNF actinide separation process and are not in the HLLW stream. Note from Table 1 that other transuranic actinides (e.g., $\mathrm{Np}, \mathrm{Am}, \mathrm{Cm}$ ) remaining in the spent fuel were not removed from the HLLW; even though some advanced aqueous separation methods under development have this potential. These actinides, if recovered, are suitable for burn-up and energy recovery in fast reactors.

4. Separation additives and corrosion products from the various aqueous separation tanks and HLLW storage vessels were added to reflect compositions based on samples of HLLW from past defense and commercial SNF recovery operations.

5. Fission product distributions in the HLLW were represented as solid oxide compounds to represent their original state in an oxide fuel pellet. Key chemicals in the fuel dissolver solution prior to the aqueous separation steps are nitric acid and water and they are retained in the HLLW after separations. The nitric acid and water are assumed removed as evaporated off gas from the high temperature melting step required for HLLW immobilization. As a result, the waste form produced from melting contains the fission products (and other metals) in the solid oxide forms they possessed in the original fuel.

The information in the first column of Table 1 was provided by PNNL and separates the components into two categories: the fuel category which depicts the numerous fission products in the HLLW as a result of the fuel's irradiation, removal from the reactor, and recycling; and the corrosion products plus processing (i.e., recycling) category, indicating the additional components in the HLLW obtained after the fuel was stored for cooling and recycled. The second category also includes the corrosion products resulting from any tanks used for interim storage of the HLLW prior to immobilization. The various HLLW components and their composition in the oxide form, as provided by PNNL, are shown in the second and third columns of Table 1 . 
Table 1 The solid oxide composition received from PNNL and the corresponding nitrate composition (as calculated in this report) representative of the projected HLLW from an advanced SNF aqueous-based separation process.

\begin{tabular}{|c|c|c|c|c|}
\hline & oxide form & $w t \%$ & nitrate form & $w t \%$ \\
\hline $\begin{array}{l}\infty \\
\text { 흔 } \\
\text { 은 } \\
\text { 언 }\end{array}$ & $\begin{array}{c}\mathrm{MgO} \\
\mathrm{P}_{2} \mathrm{O}_{5} \\
\mathrm{Cr}_{2} \mathrm{O}_{3} \\
\mathrm{Fe}_{2} \mathrm{O}_{3} \\
\mathrm{NiO}\end{array}$ & $\begin{array}{c}4.07 E-02 \\
3.10 E-01 \\
3.23 E-01 \\
3.18 E+00 \\
4.22 E-01\end{array}$ & $\begin{array}{c}\mathrm{MgO} \\
\mathrm{P}_{2} \mathrm{O}_{5} \\
\mathrm{Cr}_{2} \mathrm{O}_{3} \\
\mathrm{Fe}_{2} \mathrm{O}_{3} \\
\mathrm{NiO}\end{array}$ & $\begin{array}{l}2.06 E-02 \\
1.56 E-01 \\
1.63 E-01 \\
1.60 E+00 \\
2.13 E-01\end{array}$ \\
\hline 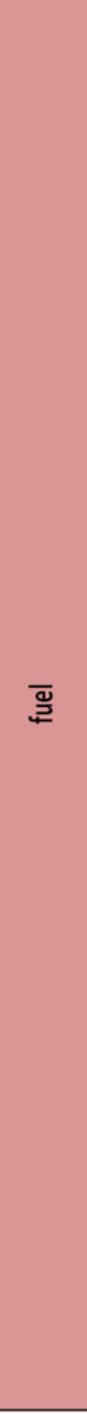 & 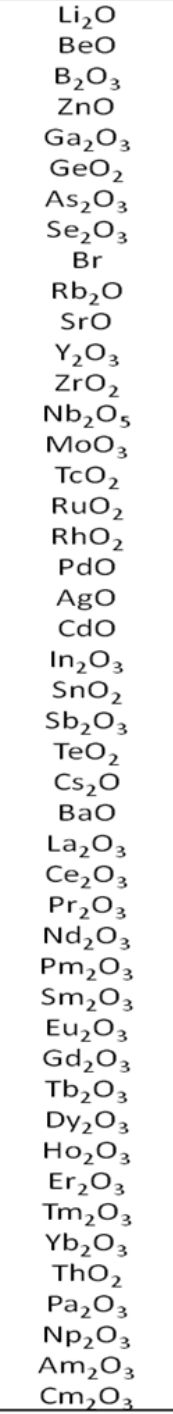 & 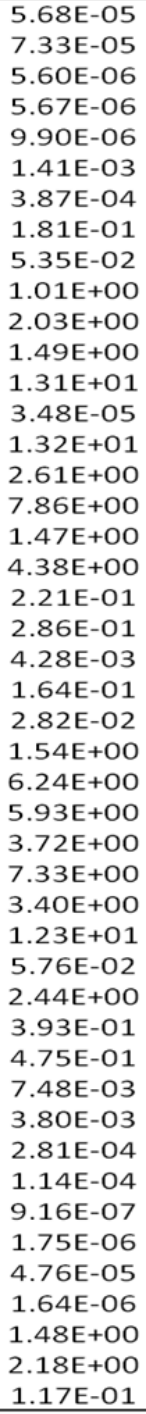 & 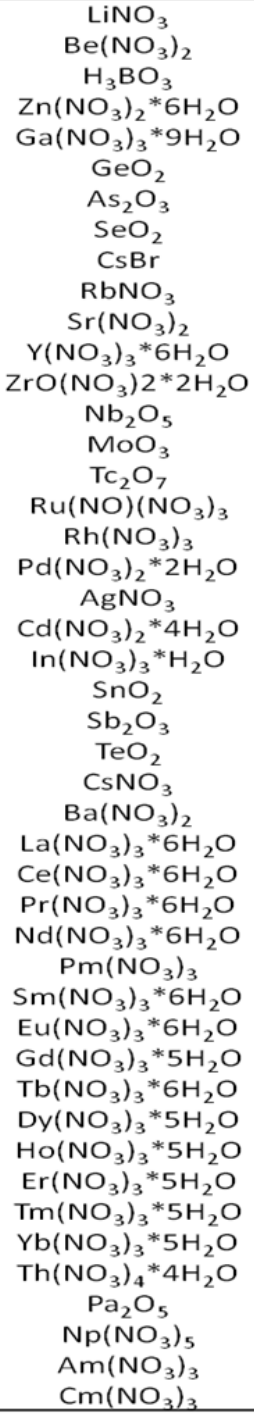 & 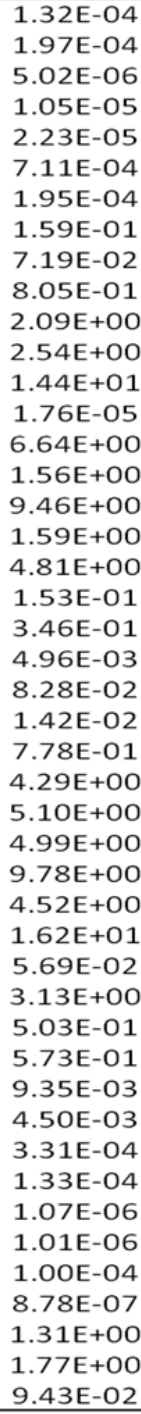 \\
\hline
\end{tabular}

Since no HLLW as a liquid nitric acid solution has been produced at full scale from an advanced SNF separation process, little empirical information is available to determine the amount of nitric acid used to dissolve the fuel as well as the composition of the resultant HLLW as a nitric acid solution. However, by using molecular weights, the numerous and various component oxides were converted into nitrate forms (if possible) based on chemistry to represent the composition of the dilute HLLW leaving the aqueous separation cycles. To determine the liquid volume and the weight percent of constituents in a dilute nitrate based HLLW from the PNNL provided oxide compositions in column 3, spreadsheet calculations were made with the following guidelines: 
1. A starting calculation basis of 100 grams of oxides.

2. A nitric acid concentration of $2.75 \mathrm{M}$ was assumed for the un-concentrated HLLW. This is a typical HLLW molar acidity based on the presence of nitric acid. Dissolution of the fuel results in a 20 to $35 \%$ reduction in the nitric acid's molarity

3. That the nitrate anions are at equilibrium with the metals in the HLLW based on the chemistry indicated in column four and the free nitrate anions are associated with a metal cation as provided in the original oxide composition.

4. The conversion calculation method stated in 3 above was the same method used when HLLW surrogates were made from solid oxide concentrations for 2012 testing in the CCIM Pilot Plant.

With the use of molecular weights for each, oxide, nitrate or hydrated nitrate compound, the number of moles of nitrate anions ( 1.31 moles/100 grams oxides) were calculated by summing the moles of all the nitrates produced when converting (where chemically allowed) each oxide species in the HLLW to its nitrate form or hydrated nitrate form. This value was then divided by $2.75 M$ to get a volume of 0.476 liters per 100 grams of oxides. Taking the reciprocal, this volume corresponds to an oxide solids content of $210 \mathrm{~g}$ of oxides/liter of dilute HLLW. The dilute HLLW volume/oxide ratio was then used to calculate the amount of each nitrate species (as well as each retained oxide species that cannot be converted to a nitrate) in the dilute HLLW as shown in fifth column of Table 1.

Table 2 provides the dilute and concentrated values (in both grams per liter and molarity) for each HLLW constituent before and after its evaporation upstream of the CCIM. Concentrated values were made based on increasing the density of the dilute HLLW to that of legacy defense HLLW, which is $\sim 1.2 \mathrm{~kg} / \mathrm{L}$. Legacy defense HLLW was chosen as a bench mark concentration level based on its thickness, consistency, viscosity and its CCIM Pilot Plant performance with respect to relatively high feed rates and sustained cold cap formation. Concentrating the HLLW from a density of $1.1 \mathrm{~kg} / \mathrm{L}$ to a density of $1.2 \mathrm{~kg} / \mathrm{L}$ requires assuming the HLLW has the equivalent density of only an aqueous mixture of nitric acid in water. The basis of this assumption is that the constituents in the HLLW are of a low enough concentration to have little effect on the solution density to be relevant for an estimated HLLW concentration,

Concentrating was done using a table and calculator for correlating nitric acid densities and nitric acid concentrations as provided by references 1 and 2. Deploying these reference methods, the density of a $1.1 \mathrm{~kg} / \mathrm{L}$ nitric acid water mixture corresponds to a nitric acid concentration of $2.75 \mathrm{M}$ or 17 wt. $\%$ at $25^{\circ} \mathrm{C}$. Note that the determined value of $2.75 \mathrm{M}$ matches the empirical average concentration for the dilute HLLW described in the previous section. This provides a level of confidence for the approach since the $1.1 \mathrm{~kg} /$ density was determined from a sampling of a surrogate liquid feed taken after the CCIM Pilot Plant test referred to in Section 1. Using the same table and calculator of references 1 and 2, the corresponding acid concentration for a nitric acid and water mixture of density $1.2 \mathrm{~kg} / \mathrm{L}$ at $25^{\circ} \mathrm{C}$ was determined to be $34 \mathrm{wt} . \% \mathrm{HNO}_{3}$ or 6.49 $M \mathrm{HNO}_{3}$. The latter is the expected nitric acid concentration for a HLLW surrogate feed to be used for testing in the CCIM Pilot Plant this year. 
Table 2 HLLW species concentrations before and after concentrating the waste via evaporation. All compositions are on a basis of 100 grams of solid oxide.

\begin{tabular}{|c|c|c|c|c|}
\hline Species & $\begin{array}{c}\text { Species } \\
\text { Concentration } \\
\text { before } \\
\text { concentrating g/L }\end{array}$ & $\begin{array}{c}\text { Species } \\
\text { Concentration } \\
\text { before } \\
\text { concentrating M }\end{array}$ & $\begin{array}{c}\frac{\text { Species }}{\text { Concentration }} \\
\frac{\text { after }}{\text { concentrating } g / L}\end{array}$ & $\begin{array}{c}\begin{array}{c}\text { Species } \\
\text { Concentration }\end{array} \\
\frac{\begin{array}{c}\text { after } \\
\text { concentrating }\end{array}}{\underline{M}}\end{array}$ \\
\hline $\mathrm{Mg}$ & 5.17E-02 & $2.13 \mathrm{E}-03$ & $2.00 \mathrm{E}-01$ & $8.22 \mathrm{E}-03$ \\
\hline$P$ & $2.84 \mathrm{E}-01$ & 9.17E-03 & $1.10 \mathrm{E}+00$ & $3.55 \mathrm{E}-02$ \\
\hline $\mathrm{Cr}$ & 4.65E-01 & 8.94E-03 & $1.80 \mathrm{E}+00$ & $3.46 \mathrm{E}-02$ \\
\hline $\mathrm{Fe}$ & $4.68 \mathrm{E}+00$ & 8.37E-02 & $1.81 \mathrm{E}+01$ & 3.24E-01 \\
\hline $\mathrm{Ni}$ & 6.97E-01 & $1.19 \mathrm{E}-02$ & $2.70 \mathrm{E}+00$ & $4.59 \mathrm{E}-02$ \\
\hline $\mathrm{Li}$ & 5.55E-05 & 8.00E-06 & $2.15 \mathrm{E}-04$ & 3.09E-05 \\
\hline $\mathrm{Be}$ & $5.55 \mathrm{E}-05$ & $6.16 \mathrm{E}-06$ & $2.15 \mathrm{E}-04$ & $2.38 \mathrm{E}-05$ \\
\hline$B$ & $3.66 \mathrm{E}-06$ & 3.39E-07 & $1.41 \mathrm{E}-05$ & $1.31 \mathrm{E}-06$ \\
\hline $\mathrm{Zn}$ & $9.58 \mathrm{E}-06$ & $1.47 \mathrm{E}-07$ & 3.70E-05 & $5.66 \mathrm{E}-07$ \\
\hline $\mathrm{Ga}$ & $1.55 \mathrm{E}-05$ & $2.22 \mathrm{E}-07$ & 5.99E-05 & 8.59E-07 \\
\hline $\mathrm{Ge}$ & $2.05 \mathrm{E}-03$ & $2.83 \mathrm{E}-05$ & $7.94 \mathrm{E}-03$ & $1.09 \mathrm{E}-04$ \\
\hline As & $6.16 \mathrm{E}-04$ & $8.22 \mathrm{E}-06$ & $2.38 \mathrm{E}-03$ & $3.18 \mathrm{E}-05$ \\
\hline $\mathrm{Se}$ & 4.72E-01 & $5.98 \mathrm{E}-03$ & $1.83 \mathrm{E}+00$ & $2.31 \mathrm{E}-02$ \\
\hline $\mathrm{Br}$ & 1.87E-01 & 1.41E-03 & 7.23E-01 & $5.44 \mathrm{E}-03$ \\
\hline $\mathrm{Rb}$ & $1.94 \mathrm{E}+00$ & $2.28 \mathrm{E}-02$ & $7.52 \mathrm{E}+00$ & $8.79 \mathrm{E}-02$ \\
\hline $\mathrm{Sr}$ & $3.61 \mathrm{E}+00$ & $4.12 \mathrm{E}-02$ & $1.39 E+01$ & $1.59 \mathrm{E}-01$ \\
\hline$Y$ & $2.46 \mathrm{E}+00$ & 2.77E-02 & $9.51 \mathrm{E}+00$ & 1.07E-01 \\
\hline $\mathrm{Zr}$ & $2.05 E+01$ & $2.24 \mathrm{E}-01$ & $7.91 \mathrm{E}+01$ & 8.67E-01 \\
\hline $\mathrm{Nb}$ & 5.11E-05 & $5.50 \mathrm{E}-07$ & $1.98 \mathrm{E}-04$ & $2.13 \mathrm{E}-06$ \\
\hline Mo & $1.84 \mathrm{E}+01$ & $1.92 \mathrm{E}-01$ & $7.12 \mathrm{E}+01$ & 7.43E-01 \\
\hline Tc & $4.14 \mathrm{E}+00$ & $4.23 \mathrm{E}-02$ & $1.60 \mathrm{E}+01$ & $1.63 \mathrm{E}-01$ \\
\hline $\mathrm{Ru}$ & $1.26 \mathrm{E}+01$ & $1.24 \mathrm{E}-01$ & $4.85 \mathrm{E}+01$ & $4.80 \mathrm{E}-01$ \\
\hline $\mathrm{Rh}$ & $2.36 \mathrm{E}+00$ & $2.29 \mathrm{E}-02$ & $9.11 \mathrm{E}+00$ & $8.85 \mathrm{E}-02$ \\
\hline $\mathrm{Pd}$ & $8.00 \mathrm{E}+00$ & 7.52E-02 & $3.09 E+01$ & $2.91 \mathrm{E}-01$ \\
\hline $\mathrm{Ag}$ & 4.05E-01 & $3.76 \mathrm{E}-03$ & $1.57 \mathrm{E}+00$ & $1.45 \mathrm{E}-02$ \\
\hline $\mathrm{Cd}$ & 5.26E-01 & $4.68 \mathrm{E}-03$ & $2.03 E+00$ & $1.81 \mathrm{E}-02$ \\
\hline In & $7.45 \mathrm{E}-03$ & $6.48 \mathrm{E}-05$ & $2.88 \mathrm{E}-02$ & $2.51 \mathrm{E}-04$ \\
\hline Sn & $2.72 \mathrm{E}-01$ & $2.29 \mathrm{E}-03$ & $1.05 \mathrm{E}+00$ & $8.85 \mathrm{E}-03$ \\
\hline $\mathrm{Sb}$ & $5.76 \mathrm{E}-02$ & 4.06E-04 & $2.23 \mathrm{E}-01$ & 1.57E-03 \\
\hline $\mathrm{Te}$ & $2.59 \mathrm{E}+00$ & 2.03E-02 & $1.00 \mathrm{E}+01$ & $7.85 \mathrm{E}-02$ \\
\hline Cs & $1.22 \mathrm{E}+01$ & 9.17E-02 & $4.71 E+01$ & $3.54 \mathrm{E}-01$ \\
\hline $\mathrm{Ba}$ & $1.12 \mathrm{E}+01$ & $8.13 \mathrm{E}-02$ & $4.32 \mathrm{E}+01$ & $3.14 \mathrm{E}-01$ \\
\hline $\mathrm{La}$ & $6.67 \mathrm{E}+00$ & $4.80 \mathrm{E}-02$ & $2.58 \mathrm{E}+01$ & $1.86 \mathrm{E}-01$ \\
\hline $\mathrm{Ce}$ & $1.32 \mathrm{E}+01$ & $9.39 \mathrm{E}-02$ & $5.08 \mathrm{E}+01$ & $3.63 \mathrm{E}-01$ \\
\hline $\mathrm{Pr}$ & $6.10 \mathrm{E}+00$ & 4.33E-02 & $2.36 \mathrm{E}+01$ & 1.67E-01 \\
\hline $\mathrm{Nd}$ & $2.23 \mathrm{E}+01$ & $1.54 \mathrm{E}-01$ & $8.60 \mathrm{E}+01$ & 5.96E-01 \\
\hline $\mathrm{Pm}$ & $1.04 \mathrm{E}-01$ & 7.17E-04 & $4.02 \mathrm{E}-01$ & 2.77E-03 \\
\hline $\mathrm{Sm}$ & $4.42 \mathrm{E}+00$ & $2.94 \mathrm{E}-02$ & $1.71 \mathrm{E}+01$ & $1.14 \mathrm{E}-01$ \\
\hline $\mathrm{Eu}$ & 7.14E-01 & $4.70 \mathrm{E}-03$ & $2.76 \mathrm{E}+00$ & $1.82 \mathrm{E}-02$ \\
\hline $\mathrm{Gd}$ & 8.67E-01 & 5.51E-03 & $3.35 \mathrm{E}+00$ & $2.13 \mathrm{E}-02$ \\
\hline $\mathrm{Tb}$ & $1.37 \mathrm{E}-02$ & 8.60E-05 & $5.28 \mathrm{E}-02$ & 3.33E-04 \\
\hline Dy & $6.95 \mathrm{E}-03$ & $4.28 \mathrm{E}-05$ & $2.69 \mathrm{E}-02$ & $1.65 \mathrm{E}-04$ \\
\hline Ho & $5.16 \mathrm{E}-04$ & $3.13 \mathrm{E}-06$ & 1.99E-03 & $1.21 \mathrm{E}-05$ \\
\hline $\mathrm{Er}$ & $2.09 \mathrm{E}-04$ & $1.25 \mathrm{E}-06$ & $8.08 \mathrm{E}-04$ & $4.83 \mathrm{E}-06$ \\
\hline $\mathrm{Tm}$ & $1.69 \mathrm{E}-06$ & $9.98 \mathrm{E}-09$ & $6.52 \mathrm{E}-06$ & $3.86 \mathrm{E}-08$ \\
\hline $\mathrm{Yb}$ & $1.62 \mathrm{E}-06$ & $9.36 \mathrm{E}-09$ & $6.26 \mathrm{E}-06$ & $3.62 \mathrm{E}-08$ \\
\hline Th & $1.76 \mathrm{E}-04$ & $7.58 \mathrm{E}-07$ & $6.80 \mathrm{E}-04$ & 2.93E-06 \\
\hline $\mathrm{Pa}$ & $3.12 \mathrm{E}-06$ & $1.35 \mathrm{E}-08$ & $1.21 \mathrm{E}-05$ & $5.22 \mathrm{E}-08$ \\
\hline $\mathrm{Np}$ & $2.83 \mathrm{E}+00$ & $1.20 \mathrm{E}-02$ & $1.10 \mathrm{E}+01$ & 4.62E-02 \\
\hline Am & $4.17 E+00$ & $1.72 \mathrm{E}-02$ & $1.61 \mathrm{E}+01$ & $6.64 \mathrm{E}-02$ \\
\hline $\mathrm{Cm}$ & $2.24 \mathrm{E}-01$ & 9.07E-04 & 8.66E-01 & $3.51 \mathrm{E}-03$ \\
\hline
\end{tabular}


To calculate the volume of the concentrated raffinate on the same $100 \mathrm{~g}$ of oxide basis, a mole balance around the evaporator is required. Using the nitric acid T-xy vapor liquid equilibrium (VLE) diagram provided in Figure 2, the resulting tie line (dashed blue line) from $34 \mathrm{wt} . \%$ at the lower liquid line to the upper vapor curve provides a condensed vapor nitric acid concentration of $\sim 9 \%$ ( orange line). Figure 2 also indicates that the bubble (boiling) point of a $2.75 \mathrm{M}\left(17 \mathrm{wt}\right.$. \%) nitric acid water mixture is $\sim 110^{\circ} \mathrm{C}$ for evaporative concentration to $6.49 \mathrm{M}$ $\mathrm{HNO}_{3}$.

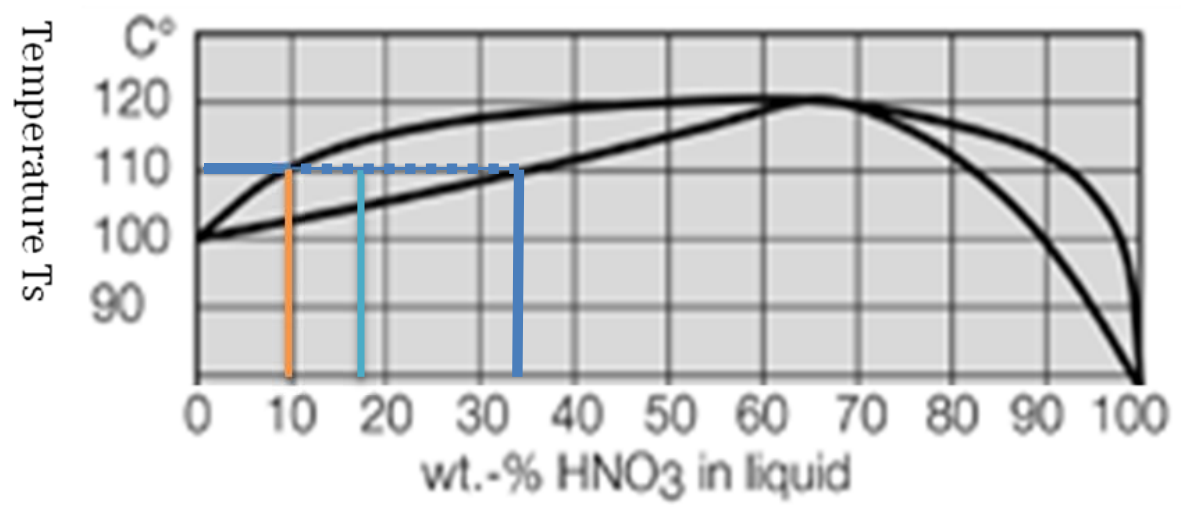

Figure 2 The T-xy VLE for nitric acid in water

The aqua and dark blue lines in the T xy VLE diagram of Figure 2 respectively mark the concentrations of nitric acid in the liquid phase before and after concentrating the HLLW. The orange line represents the concentration of nitric acid in the vapor form in equilibrium with the concentrated HLLW (i.e., 34 wt. \% nitric acid). An acid concentration of $\sim 9$ wt. \% for the vapor phase is equal to a $1.44 \mathrm{M}$ solution with a density of $1.047 \mathrm{~g} / \mathrm{l}$ based on the use of references 1 and 2. Since the number of moles of nitric acid (on a 100 gram oxide basis) going into the evaporator with the dilute HLLW is equal to the number of moles of nitric acid in the vapor phase leaving the evaporator plus the number of moles of nitric acid in the concentrated HLLW to be fed to the CCIM, the nitric acid mole balance around the evaporator (on a 100 gram oxide basis) is

$$
2.75 \mathrm{M} \mathrm{HNO}_{3}(0.476)=6.49 \mathrm{M} \mathrm{HNO}_{3}(\mathrm{x})+1.44 \mathrm{M} \mathrm{HNO}_{3}(0.476-\mathrm{x})
$$

Solving for $\mathrm{x}$ results in a concentrated HLLW volume equal to $0.123 \mathrm{~L}$ per 100 grams of oxides. Using this volume, the increased concentrations of the metal species/fission products were calculated for the concentrated HLLW as shown, in units of both $\mathrm{g} / \mathrm{l}$ and molarity, in the fourth and fifth columns of Table 2 .

Table 3 shows the total volumes of HLLW and the oxide solids content before and after concentration. The values of Table 3 along with the estimated concentrated HLLW nitric acid molarity of 6.49 has utility in specifying concentrated nonradioactive surrogate composition recipes for testing as feed to the CCIM Pilot Plant. 
Table 3 Volume and solids content before and after concentrating the HLLW

\begin{tabular}{|l|c|c|}
\hline & Before Concentrating & After Concentrating \\
\hline Volume : L/100grams of oxide & 0.476 & 0.123 \\
\hline $\begin{array}{l}\text { Solids Content: grams of } \\
\text { oxide/L }\end{array}$ & 210 & 813 \\
\hline
\end{tabular}

\section{Proposed Concept for Concentrating HLLW}

As stated earlier, the deployed method of concentrating the HLLW to facilitate melting, through the use of calcination to form a particulate solid is presently not desired over concerns of contamination containment and equipment logistics.

As indicated in this study, these issues are overcome with the deployment of evaporation for concentration; and in particular through the use of thermo syphon evaporation (refer to references 3 and 4). Even though thermo syphon evaporation does not achieve the volume reduction (e.g. $>80 \%$ ) and denitrification of calcination, it achieves a volume reduction of nearly $75 \%$ and partially reduces the NOx levels from the CCIM. However, unlike calcination, sufficient nitrates will still be sent to the melter requiring NOx abatement (i.e. selective catalytic reduction/ SCR) for the CCIM off-gas stream. Thermo syphon evaporation upstream of the CCIM provides a compromise in reducing the CCIM off-gas volume, reducing the amount of CCIM energy wasted in denitration and evaporation, building controllable cold caps on the melt surface-as evidenced with the melting of legacy defense HLLW, increasing melter feed rates and building melter bed at a rate to facilitate efficient canister filling.

Thermo syphon evaporators are a physical process that may be operated batch, semi batch or continuous. Thermo syphon evaporators take advantage of the natural temperature differences established in its design and operation. The dilute feed, or in this case, the SNF recycling derived HLLW, is fed at the top of the evaporator's loop. From there it enters a shell and tube heat exchanger or evaporator reboiler. Steam used for heating is isolated from the HLLW by entering the shell side of the reboiler. The steam exits the reboiler shell as condensation after it transfers its enthalpy to the HLLW feed in the tubes. Heated HLLW in the tubes expands as a vapor/liquid mix into the tube manifold and then exits into the larger de-entrainment tank section of the evaporator. The design of the thermo syphon evaporator ensures that the height of the HLLW feed vapor/ liquid mix in the reboiler is always at the same level of the concentrated liquid in the larger tank (below the de-entrainment section) and the incoming HLLW feed tube. The concentrated HLLW as condensing vapor in the de- entrainment section flows down to the large tank facilitating the natural circulation of the incoming dilute HLLW feed to the evaporator's reboiler to maintain constant levels. Purged pressure probes are deployed to measure the density of the concentrating HLLW. Evaporator operations will require a density increase of less than $10 \%$ to transfer a HLLW batch to the CCIM feed tank for melting at a higher concentration level. Simple automation controls the steam flow to maintain the desired $110^{\circ} \mathrm{C}$ reboiler temperature.

The vapor leaving the evaporator can be condensed and the liquid sent to an acid fractionator (see reference 5). The acid fractionator serves as a distillation column, allowing the nitric acid to be concentrated to any molarity (e.g., $1.44 M$ to $7 M$ ). To provide some cost efficiency, this nitric acid, even though contaminated, is available for reuse in the SNF dissolver upstream of the separations process. 


\section{References}

1. Perry's Chemical Engineer's Handbook, $5^{\text {th }}$ Edition, page 3-96, McGraw Hill, 1980

2. Handymath.com, 1/4/2013, the complete Aqueous Nitric Acid Solutions Density-Concentration Calculator, http://www.handymath.com/cgi-bin/nitrictictble2.cgi.

3. B. Ya. Silverman, M.N. Makarychev-Mikhailov, D.V. Reeboks, A. Yu. Shadrin, E.A. Puzikov, V.F. Gorn, A.S. Skobtsov, V. K. Koltyshev, and I. B. Ivanov, Nitric Acid Purification from Admixtures of Volatile Acids by Fractionation during Waste Evaporation at a Spent Nuclear Fuel Reprocessing Company, Inorganic Technology, Page 390, August 18, 2009.

4. T. Bond Calloway, Jr., William R. Wilmarth. Jamal E. Josephs, Russell E. Eibling, David A. Crowley, Christopher J. Martino, Michael E. Stone, Carl D. Barnes, Alexander S. Choi, Mark A. Baich, Carol M. Jantzen, Robert A. pierce, William E,. Daniel, Thomas L. White, Jermaine D. Johnson, Krishna, Vijayaraghavan, Alex, Nikolov, Darsh T. Wasan, Radioactive Waste Evaporation: Current Methodologies Employed for the Development, Design and Operation of Waste Evaporators at the Savannah River site and Handford Waste Treatment Plant, $9^{\text {th }}$ International Conference on Radioactive Waste Management and Environmental Remediation, September 21-25, 2003, Examination School, Oxford England, icem03-4515, WSRC-MS-2003-00050, Rev.0.

5. C.V. McIntyre, R.E. Schindler, Technical Bases for Treatment of PEW Condensates by Acid Fractionation, WINCO, August 1986. 